\title{
Investigations into suitability of Trifolium occidentale as a host plant for two common pasture pests
}

\author{
P.J. Gerard and K.M. O’Donnell \\ AgResearch, Ruakura Research Centre, Private Bag 3123, Hamilton, New Zealand \\ Corresponding author: pip.gerard@agresearch.co.nz
}

\begin{abstract}
Western clover (Trifolium occidentale) is a diploid perennial clover that is reported to be one of the progenitors of white clover (Trifolium repens). The ability to produce hybrids between $T$. repens and T. occidentale provides an opportunity to introduce factors to improve white clover tolerance to common stress factors. A series of assays was undertaken to compare the feeding and performance of two contrasting pests on two T. occidentale lines and two T. repens cultivars. Clover root weevil (Sitona lepidus) adults showed a preference for $T$. repens, but this diminished if weevils had been previously exposed to T. occidentale. Weevil longevity, feeding levels and oviposition were comparable over 32 days, indicating T. occidentale is a host plant for adult S. lepidus. Clover flea (Sminthurus viridis) showed a strong preference for $T$. repens over T. occidentale in a choice test and higher feeding levels on $T$. repens in the no-choice test.
\end{abstract}

Keywords choice test, no-choice test, Sminthurus viridis, Sitona lepidus.

\section{INTRODUCTION}

Western clover (Trifolium occidentale Coombe) is a diploid stoloniferous perennial clover originating from coastal habitats, especially rocky outcrops, on the Gulf Stream coasts of Portugal, Spain, France, Ireland and the United Kingdom. The species so closely resembles white clover (Trifolium repens L.) that it was not recognised as a separate species until 1960 (Coombe 1961). It is of high interest to white clover breeders because the white clover allotetraploid genome is derived from $T$. occidentale and another diploid ancestor, T. pallescens Schreb. (Williams et al. 2012). It is a useful model plant for determining gene function in white clover as it has a small genome, forms hybrids with $T$. repens, has both self-fertile and self-incompatible breeding lines, a short generation time, and forms the same symbiotic relationship with Rhizobium spp. bacteria (Williams et al. 2009). In addition, it is considered a useful genetic resource to improve the resistance of white clover cultivars to common stressors such as diseases and drought (Pederson \& McLaughlin 1989; Williams et al. 2009).

The arrival of clover root weevil (Sitona lepidus Gyllenhal) in New Zealand highlighted the vulnerability of modern clover cultivars to pests (Crush 2005). As the native distribution of S. lepidus, a specialist Trifolium spp. herbivore, overlaps that of T. occidentale, the clover may also have useful heritable mechanisms to protect against attack. While it has been shown T. occidentale can host the nematodes Meloidogyne trifoliophila, M. hapla, M. incognita and M. javanica (Mercer \& Miller 1997), there is no published information on whether the clover is a suitable host for S. lepidus or other common clover pests. 
The simplest and most common first step in assessing if a plant is acceptable as a host plant is a feeding assay where level of feeding on the test plant is compared with that on a known host plant. Sitona lepidus adults make a distinctive U-shaped notch on the leaflet edge at each feeding episode, the size of which varies with adult size. Therefore S. lepidus feeding activity is usually assessed by counting notches (Murray \& Clements 1994; Murray 1996a; Murray \& Willoughby 1998; Gerard \& Crush 2003). In addition, when in a reproductive state, $S$. lepidus females lay eggs continuously if provided quality clover foliage and these can be readily collected from the cage base. Thus egg counts obtained during no-choice feeding assays can provide additional information on S. lepidus host plant suitability (Murray 1996b; Gerard \& Crush 2003). In contrast, clover flea (Sminthurus viridis L.) feeds on the mesophyll (Maclagan 1932) leaving one cuticle layer of the leaf intact. The combination of relatively poor feeding scar definition and the abundance and size variation in scars makes direct counts or leaf area scans difficult. Therefore, most authors have visually scored the severity of damage on control and test plants (Cooper 1994; Bishop \& Barchia 2003).

The objective of this study was to compare levels of foliar feeding on $T$. repens and T. occidentale by adult S. lepidus and S. viridis, a generalist herbivore that is a sporadic and at times a serious pest of white clover.

\section{MATERIALS AND METHODS}

The experiments were run at the Ruakura Research Centre, Hamilton, in summer 2013/14. Seeds of two T. repens cultivars (Grasslands Kopu II and the inbred Crau S9 2A) and two T. occidentale populations (48 and AZ4270) were obtained from the Margot Forde Forage Germplasm Centre at Palmerston North. Kopu II was selected as an industry standard while the inbred clover was reported to be less resilient to common stresses than outcrossed clovers. Over 60 plants of each clover (hereafter referred to as plant lines) were grown in commercial potting mix, in individually-labelled pots in a glasshouse.
Within each assay (described below), a leaf from a different plant was used in each replicate. Care was taken to select mature leaves of approximately equal size, which meant picking the smaller $T$. repens leaves and the largest T. occidentale leaves. Where this was not possible, additional T. occidentale leaves were added to give a visually approximately equal leaf area.

The invertebrates were collected from clover patches in nearby ryegrass/T. repens pastures using a modified blower-vac and were handsorted in the laboratory.

\section{Sitona lepidus assays}

Choice tests were carried out in numbered Petri dishes lined with damp filter paper that had been marked into four labelled quarters with pencil. Clover leaves of similar size taken from each plant line were placed in the appropriate quadrat and the plant identification recorded. One S. lepidus adult from the field collection was placed in each Petri dish. There were 20 replicates and the assay was held in a controlled environment room at $20^{\circ} \mathrm{C}$ and $16 \mathrm{~h}$ photoperiod. The number of feeding notches on each leaf was assessed at $24 \mathrm{~h}$.

A no-choice assay was run in vented $100 \mathrm{ml}$ specimen vials with one clover leaflet and one weighed female weevil per vial. The vials were used rather than Petri dishes as vials simplified maintenance and assessments, and reduced the chance of handling injuries to weevils during these processes. The weevils had been caged individually beforehand and only those that had laid eggs were used. There were 14 replicates for each plant line and the assay was held in a controlled environment room at $20^{\circ} \mathrm{C}$ and $16 \mathrm{~h}$ photoperiod. After $24 \mathrm{~h}$, notches and the number of eggs laid were recorded. The vial was cleaned and the old leaf was replaced with a fresh leaf from the same plant. The assay continued over the next 32 days with assessments as time permitted (17 in total). When more than $48 \mathrm{~h}$ had passed since the previous assessment, only the number of eggs was recorded.

A second choice test was carried out using weevils from the no-choice assay above to ascertain if feeding preference was modified by 
previous 32 day experience. Petri dishes were lined with damp filter paper that had been marked into two labelled sectors with pencil. Clover leaves of similar leaf area from T. repens $\mathrm{cv}$. Kopu II and T. occidentale 48 were placed in the appropriate sector and a single S. lepidus that had been feeding solely on either T. repens Kopu II or T. occidentale AZ 4270 for the previous month was added to each dish. There were 12 replicates of weevils from each treatment and the assay was held in the same conditions and assessed as described in the above choice assay.

\section{Sminthurus viridis assays}

Choice and no-choice assays were carried out in test apparatus described by Eden et al. (2005). Sminthurus viridis, freshly collected from the field, were caged in vented $100 \mathrm{ml}$ specimen vials and the petioles of the test clover leaves were threaded through holes into a water source below. Around $1 \mathrm{~mm}$ of sieved soil was put in the base of the cages; this improves $S$. viridis longevity by absorbing and buffering condensation.

In the no-choice assay, there were 10 replicates for each of the four plant lines, each consisting of a single leaf and a single $S$. viridis. The choice assay was set up in an identical manner, except each vial contained a T. repens Kopu II leaf (identified by a mark next to the hole for the petiole) and a leaf from one of the other three clovers.

The assays were held in a controlled environment room at $15^{\circ} \mathrm{C}$ and $16 \mathrm{~h}$ photoperiod and assessed at $24 \mathrm{~h}$. Sminthurus viridis survival was assessed and feeding damage on each leaflet of the trifoliate leaf was scored from 0 (no damage) to 4 (over half leaf area damaged) and added to obtain an overall score for each leaf. Nochoice replicates with dead $S$. viridis were rerun using a new $S$. viridis to investigate if mortality was related to the test clover.

\section{Statistical analyses}

The $S$. viridis data and S. lepidus choice data were analysed by ANOVA, and means in the choice tests compared using a paired t-test. The S. lepidus no-choice data were square-root transformed and ANOVA was conducted with weevil weight as a covariate. The relationship of weevil weight, feeding notches and eggs laid was investigated using regression analysis.

\section{RESULTS}

\section{Sitona lepidus assays}

When given a choice, S. lepidus adults showed a significant preference for $T$. repens over T. occidentale (Table 1), but differences between plant lines within the same species were not significant. In the second choice assay, previous feeding treatment influenced the acceptability of T. occidentale (Figure 1). Thus, those weevils prefed $T$. repens showed a significant preference for T. repens $(\mathrm{P}<0.001)$, whereas the preference between $T$. repens and $T$. occidentale was statistically insignificant for those pre-fed on T. occidentale for 32 days. Weevils that had previously fed on $T$. occidentale tended to feed more than those that had previously fed on T. repens but this was not statistically significant $(\mathrm{P}=0.085)$.

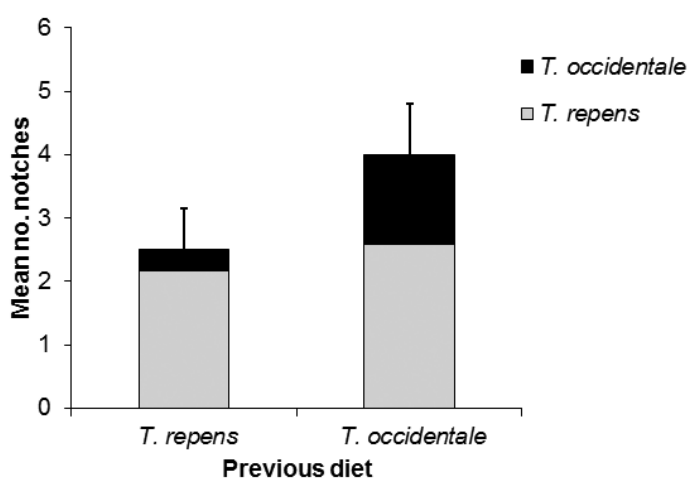

Figure 1 Effect of previous clover diet on feeding notches produced by S. lepidus adults after $24 \mathrm{~h}$ when given a choice of T. repens and T. occidentale. Error bars denote SE for total notches.

Only two weevils died, one from each plant species, during the no-choice assay. Within plant species, a similar level of notching was recorded. While it does appear fewer eggs were laid by adults held on T. occidentale AZ4270 compared to the other clovers (Figure 2), the differences were not statistically significant when adult weight was used as a covariate. The total numbers of eggs 
Table 1 Mean number of notches on leaves after $24 \mathrm{~h}$ when S. lepidus adults had the choice of four clovers.

\begin{tabular}{llcc}
\hline Species & Plant line & Notches (plant species) & Notches (plant line) \\
\hline T. repens & Kopu II & 1.35 & 1.15 \\
& Crau S9 2A & & 1.55 \\
T. occidentale & AZ4270 & 0.375 & 0.30 \\
& 48 & & 0.45 \\
LSD $(\mathrm{P}=0.05)$ & & 0.52 & 0.71 \\
\hline
\end{tabular}

laid per adult was correlated with adult weight $\left(\mathrm{P}<0.001 ; \mathrm{y}=15 \mathrm{x}-9.5, \mathrm{R}^{2}=0.22\right)$ and while weevil weight was relatively well distributed across the clover treatments $(\mathrm{P}=0.21)$, there was large variability in eggs laid, especially towards the end of the experiment. The number of eggs laid per adult declined after a peak in week 2 , with over $35 \%$ of weevils having ceased oviposition by the final assessment.

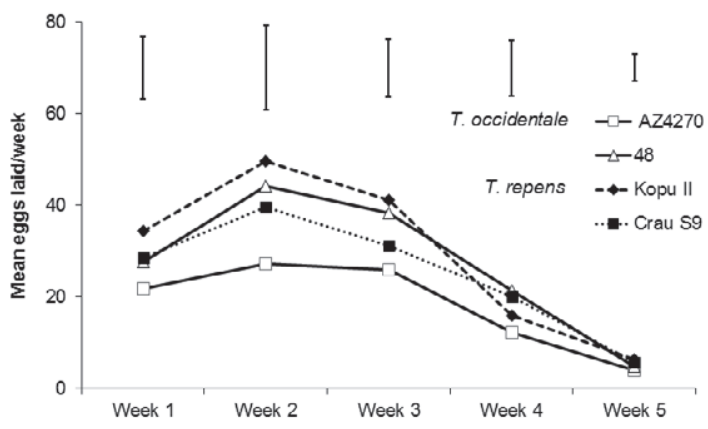

Figure 2 Pattern of oviposition by S. lepidus adults when individually maintained on four different clovers over 5 weeks. Means adjusted for covariation in adult weights. Error bars denote SED.

\section{Sminthurus viridis assays}

In the no-choice assay, damage by $S$. viridis was significantly greater on $T$. repens than on T. occidentale $(\mathrm{P}<0.001)$, and there was no difference between CrauS9 2A and T. occidentale or plant lines within species (Table 2). There was no effect on clover flea survival. When $S$. viridis were given a choice between $T$. repens cv. Kopu II and one of the other three clovers, Kopu II was preferred, though the difference was only significant for T. occidentale AZ4270 $(\mathrm{P}<0.01)$ (Figure 3).

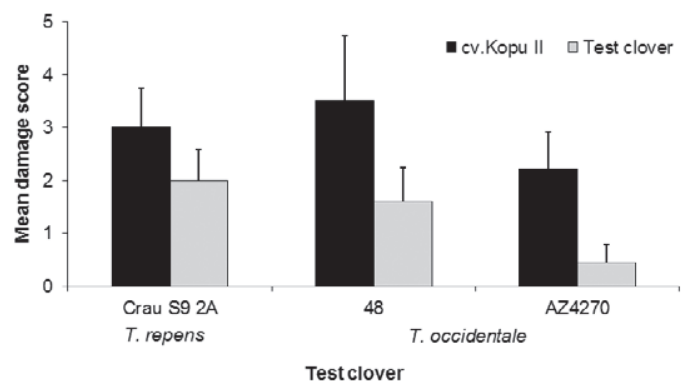

Figure 3 Comparison of feeding severity when $S$. viridis was given the choice between $T$. repens cv. Kopu II and a test clover. Error bars denote SE.

Table 2 Mean S. viridis damage scores on leaves from four clovers after $24 \mathrm{~h}$ in a no-choice assay.

\begin{tabular}{llcc}
\hline Species & Plant line & Score (plant species) & Score (plant line) \\
\hline T. repens & Kopu II & 3.53 & 4.03 \\
& Crau S9 2A & & 3.03 \\
T. occidentale & AZ4270 & 1.86 & 1.97 \\
& 48 & & 1.74 \\
LSD $(\mathrm{P}=0.05)$ & & & \\
\hline
\end{tabular}




\section{DISCUSSION}

Previous studies have shown that S. lepidus adults feed almost exclusively on Trifolium spp. and have preferences within the genus, with T. repens being highly preferred and T. dubium Sibth. rejected (Murray \& Clements 1994; Hardwick 1998). There are also within-species differences. For instance, reduced feeding, adult longevity and oviposition have been associated with red clover $T$. pratense L. breeding lines containing high phyto-oestrogen levels (Gerard et al. 2005; Murray et al. 2007). In contrast, S. viridis has a wide host range (Holdaway 1927). However, it is known mainly as a pest of Fabaceae, in particular T. repens and lucerne (Medicago sativa L.). Sminthurus viridis has also shown feeding preferences between cultivars (Cooper 1994).

Assays in the present study show that T. occidentale is a suitable host plant for adult S. lepidus and testing is currently underway to confirm it supports larval development. While adults that had never previously fed on $T$. occidentale preferred $T$. repens, there is evidence that they become habituated to T. occidentale following exposure. In addition, the pattern of feeding, oviposition and survival on T. occidentale appeared similar to that on T. repens over the 32-day assessment. The termination of oviposition by adults in this experiment was not associated with feed quality, rather it is thought to be associated with depletion of sperm in these long-lived weevils that would normally mate more frequently than 30 days. Sitona lepidus females store sperm in their spermathecae and cessation of oviposition by females with empty spermathecae has been reported previously (Gerard et al. 2005).

Sminthurus viridis also showed a preference for $T$. repens over $T$. occidentale, but as the assays were limited to $24 \mathrm{~h}$, it is not known if prolonged exposure influences fecundity or longevity.

It is possible that the physical leaf structure of T. occidentale contributes to the feeding preferences, in particular that of S. viridis, which feeds on the mesophyll (Maclagan 1932). In comparison to T. repens, T. occidentale leaves tend to have thicker epidermal layers, with a matt upper surface and a very glossy lower surface. However, there may be also biochemical differences that interfere with feeding cues, such as antifeedants or repellents (Smith \& Clement 2012).

In conclusion, while $T$. occidentale was fed on by both pest species, it was generally less favourable for them compared to T. repens. This reinforces the view of Williams et al. (2009) that T. occidentale is a good species to investigate for resistance against pest stress. While longer duration experiments are needed to confirm that T. occidentale supports development and survival of all life stages, $S$. lepidus appears to be a good species to use in this work although pre-selection for adult weevils of similar size is recommended to reduce variability.

\section{ACKNOWLEDGEMENTS}

The authors wish to thank Derrick Wilson for the insect field collections and Catherine Cameron for statistical analyses. The research was supported by a T. R. Ellett Agricultural Research Trust Grant and MBIE Core funding to AgResearch.

\section{REFERENCES}

Bishop AL, Barchia IM 2003. Relationships between the lucerne flea, Sminthurus viridis (L.) (Collembola: Sminthuridae), and damage to lucerne. Australian Journal of Entomology 42: 304-310.

Coombe DE 1961. Trifolium occidentale, a new species related to $T$. repens $\mathrm{L}$. . Watsonia 5: 68-87.

Cooper BM 1994. Screening a range of white clover and two red clover lines for relative tolerance to clover flea. Proceedings of the 47th New Zealand Plant Protection Conference: 287-288.

Crush JR, Cooper, B.M., Woodfield, D.R., Gerard, P.J. 2005. Development of clovers that are tolerant to clover root weevil. Proceedings of the New Zealand Grassland Association 67: 23-27. 
Eden TM, Wilson DJ, Hackell DL 2005. Assays to determine the predatory ability of Pergamasus against clover flea. New Zealand Plant Protection 58: 131-134.

Gerard PJ, Crush JR 2003. Feeding habituation to red clover by clover root weevil adults. New Zealand Plant Protection 56: 129-132.

Gerard PJ, Crush JR, Hackell DL 2005. Interaction between Sitona lepidus and red clover lines selected for formononetin content. Annals of Applied Biology 147: 173-181.

Hardwick S 1998. Laboratory investigations into feeding preferences of adult Sitona lepidus Gyllenhal. Proceedings of tohe 51st New Zealand Plant Protection Conference: 5-8.

Holdaway FG 1927. The bionomics of Smynthurus viridis, Linn., the South Australian lucerne flea. Pamphlet. Council for Scientific and Industrial Research, Commonwealth of Australia, Melbourne. 23 p.

Maclagan DS 1932. An ecological study of the "Lucerne Flea" (Smynthurus viridis, Linn.). Bulletin of Entomological Research 23: 101145.

Mercer CF, Miller KJ 1997. Evaluation of 15 Trifolium spp. and of Medicago sativa as hosts of four Meloidogyne spp. found in New Zealand. Journal of Nematology 29: 673-676.

Murray PJ 1996a. Evaluation of a range of varieties of white clover for resistance to feeding by weevils of the genus Sitona. Plant Varieties \& Seeds 9: 9-14.

Murray PJ 1996b. Influence of food source on feeding, longevity and fecundity of Sitona flavescens (Coleoptera: Curculionidae), a major pest of white clover in the UK. In: Frame J ed. Recent Research and Development on White Clover in Europe. REU Technical Series 42. www.fao.org/docrep/v9968e/ v9968e9960t.htm (accessed 19 May 2014).
Murray PJ, Cheung AKM, Abberton MT 2007. Intraspecific variation in Trifolium pratense: impact on feeding and host location by Sitona lepidus (Coleoptera, Curculionidae). Journal of Pest Science 80: 51-57.

Murray PJ, Clements RO 1994. Investigations of the host feeding preferences of Sitona weevils found commonly on white clover (Trifolium repens) in the UK. Entomologia Experimentalis et Applicata 71: 73-79.

Murray PJ, Willoughby B 1998. Feeding preferences of Sitona lepidus (clover root weevil) on Trifolium spp. in New Zealand. Tests of Agrochemicals and Cultivars No. 19: 58-59.

Pederson GA, McLaughlin MR 1989. Resistance to viruses in Trifolium interspecific hybrids related to white clover. Plant Disease 73: 997999.

Smith CM, Clement SL 2012. Molecular bases of plant resistance to arthropods. Annual Review of Entomology 57: 309-328.

Williams WM, Ellison NW, Ansari HA, Verry IM, Hussain SW 2012. Experimental evidence for the ancestry of allotetraploid Trifolium repens and creation of synthetic forms with value for plant breeding. BMC Plant Biology: 55.

Williams WM, Griffiths AG, Hay MJM, Richardson KA, Ellison NW, Rasmussen S, Verry IM, Collette V, Hussain SW, Thomas RG, Jones CS, Anderson C, Maher D, Scott AG, Hancock K, Williamson ML, Tilbrook JC, Greig M, Allan A 2009. Development of Trifolium occidentale as a plant model system for perennial clonal species. In: Yamada T, Spangenberg $\mathrm{G}$ ed. Proceedings of the 5th International Symposium on the Molecular Breeding of Forage \& Turf, 17 July 2007, Sapporo, Japan. Springer, New York. Pp. 45-53. 